\title{
CHEMICAL STUDIES OF THE BLOOD IN HIGH INTESTINAL OBSTRUCTION
}

\author{
II. The Relation between "Toxemia" \\ and Chemical Changes
}

By WILLIAM DeWITT ANDRUS, GEORGE M. GUEST, RICHARD F. GATES,
AND ALTA ASHLEY

(From the Children's Hospital Research Foundation and the Departments of Surgery and of Pediatrics, College of Medicine, University of Cincinnati, Cincinnati)

(Received for publication October 22, 1931)

In the preceding paper (Guest and Andrus, 1932) certain of the principal changes occurring in the blood of dogs following simple pyloric or mid-duodenal obstruction have been discussed. Experiments were reported in which the distribution of phosphorus in the blood of dogs with obstruction was determined, and changes in various fractions of the blood phosphorus were correlated with other chemical changes of the blood which are generally known to be associated with intestinal obstruction. The greatest change in the blood phosphorus was in that fraction designated as the "organic acid-soluble ester-P" practically all of which is contained in the cells. Changes in the chloride content of both plasma and cells were compared with concomitant changes in the distribution of phosphorus, and a close correlation between the progressive losses of chloride from the blood cells and the increases of the ester-P of the cells was demonstrated. From these findings it was concluded that in the acid-base equilibrium of the cells these organic phosphorus compounds had some sort of a reciprocal relationship to the cell chloride, and that as these phosphorus compounds increased they were bound to the alkali in the cells from which chloride was lost, much as $\mathrm{HCO}_{3}{ }^{\prime}$ is known to be retained by the alkali of the blood from which $\mathrm{Cl}^{\prime}$ is lost. In those experiments it was also shown that the parenteral administration of $\mathrm{NaCl}$ solution prevented increases of ester-P in the cells to about the same degree that it prevented losses of chloride.

The two theories most commonly accepted in explanation of the cause of death in intestinal obstruction are: (1) that death is due to dehydration and disturbance of the acid-base equilibrium of the body which follows the loss of electrolytes and water by vomiting and by failure of reabsorption of gastro-intestinal secretions from the obstructed bowel; (2) that death is due to a state of intoxication of the tissues brought about by toxic substances absorbed from the obstructed bowel. 
The efficacy of the administration of $\mathrm{NaCl}$ solution in prolonging the life of animals with simple experimental high obstruction is one of the strongest indications that in this condition the loss of water and electrolytes is the principal lethal factor; on the other hand, with "closed loops" or in obstruction with strangulation such treatment is less efficacious and in these circumstances the factor of toxemia appears to have greater importance.

Clinically, one seldom encounters circumstances capable of producing the picture of simple obstruction as it is experimentally produced in animals, because constrictions and other factors introduce the complications of strangulation in a high percentage of cases. With strangulation of the intestine, death occurs much more quickly than in simple obstruction, and much work has been done to demonstrate that in such cases the greater severity of symptoms is due to toxic substances which appear in the obstructed bowel. Filtrates and certain extracts of the bowel contents from above the point of obstruction are extremely toxic when injected into animals, and many attempts have been made to isolate and identify the substance, or substances, responsible for this toxicity. A review of this work may be found in the article by Cooper (1928). Whipple and his collaborators (1916) believed the toxic substances to be of proteose nature, while Gerard (1922) and others have pointed out the similarity in the pharmacologic effects of these extracts and of histamine. Most of the evidence accumulated from many different studies indicates that the toxic agent is some product of protein degradation, probably several related substances, and that many of the properties and effects of these substances are like those of histamine. Apparently the toxic substance is not absorbed by the normal mucosa (Davis (1914), Murphy and Brooks (1915)) but it has been demonstrated that the mucosa of the bowel above the point of obstruction is not normal, that increased tension within the bowel may cause absorption to take place (Stone and Firor (1924)) and that breaks in the continuity of the mucosa may be produced (Murphy and Brooks (1915), Van Buren (1920)) which allow the toxic substance to enter the tissues.

The presence of toxic substances in the obstructed bowel cannot be denied, but there has been much controversy over their importance in causing death, compared to the importance of the losses of electrolytes and the accompanying chemical changes of the body fluids. The studies to be reported here were undertaken with the idea that these two theories of the cause of death in intestinal obstruction could be better correlated, and that the chemical changes and the "toxemia" could be demonstrated to be interdependent. Dragstedt (1928) has already postulated such a relationship, as follows: "the toxic fractions in obstruction fluids are powerful secretogogues, and when injected 
into dogs cause a marked augmentation of gastric, pancreatic and intestinal secretion. Accordingly it seems probable from this as well as other evidence obtained by other workers, that the fall in blood chlorides in obstruction is due to their accelerated passage into the alimentary tract and failure of reabsorption."

In the experiments here described, histamine is employed as a known substance which is at least closely related to the toxic substances present in and absorbable from the obstructed bowel. Injected subcutaneously, histamine stimulates a rapid flow of gastric juice of high $\mathrm{HCl}$ content. In normal animals such injections cause only slight lowering of the blood chlorides, even when given at frequent intervals and continued over a long period (Lim and Ni (1926), Drake and Tisdall (1926)); presumably this is because most of the secreted gastric juice is reabsorbed after passing through the pylorus. However, if the flow of gastric juice thus stimulated is allowed to escape, the repeated injections of histamine are rapidly followed by marked blood chemical changes and death. Lim and Ni reported experiments in which dogs with Pavlov pouches were subjected to hourly subcutaneous injections of histamine in doses of $0.2 \mathrm{mgm}$. per kilogram body weight. One such dog (G. 17), given increasing doses of histamine, averaging 1.9 mgm. per hour, succumbed at the end of 10 hours; during this time the chloride of the whole blood fell from $308 \mathrm{mgm}$. per $100 \mathrm{cc}$. (87 mM.) before the injections to $222 \mathrm{mgm}$. per $100 \mathrm{cc}$. $(62.7 \mathrm{mM}$.) at the 10 th hour. "Gastric secretion was obtained up till the last, the total secreted being $743 \mathrm{cc}$. of juice and $3190 \mathrm{mgm}$. of $\mathrm{Cl}$. . in spite of the dehydration and large amount of $\mathrm{Cl}$ lost, amounting in one animal to 49 per $100 \mathrm{cc}$. of the total body $\mathrm{Cl}$, the gastric glands continue to secrete." Similar results were obtained when unoperated animals were injected with repeated doses of histamine while the gastric secretions were continuously aspirated by means of a Rehfuss tube. A gastrectomized $\mathrm{dog}$, on the other hand, showed no fall in the blood $\mathrm{Cl}$ after histamine injections. Two points may be considered established by such experiments as these: first, that the secretion of $\mathrm{HCl}$ with the gastric juice is the fundamental cause of the fall of the blood chloride when these secretions are lost from the body; secondly, that histamine will markedly accelerate such losses.

Certain objections may here be made to some of the conclusions drawn from previous experimental studies of this problem in which various preparations of filtrates or toxic substances isolated from the contents of the obstructed bowel were injected intravenously to prove their toxicity in normal animals. Such an injection may provoke those symptoms generally known as "shock," and immediate death, but clinically one rarely sees such fulminant progress of symptoms leading to death. Histamine when injected intravenously immedi- 
ately provokes a train of severe symptoms, whereas subcutaneous injections have less severe effects which may be considered more physiologic in nature. The slow absorption of the toxic substances from the bowel, when this does occur, must have effects more nearly like those of subcutaneous injections than like those of a large overwhelming dose suddenly injected intravenously. Moreover, the injection of a large dose of toxic substance, either intravenously or subcutaneously, may be followed by a severe reaction which is not necessarily simply an exaggeration of the effect of a small dose. If one is to reproduce the conditions that are encountered clinically, it would seem that the repeated subcutaneous injections of very small doses of these toxic substances, at short intervals, should more nearly duplicate the conditions imposed by their gradual absorption into the tissues from the obstructed bowel; this method was, therefore, employed in the experiments that follow.

\section{EXPERIMENTAL}

Methods: The methods used in the experiments were the same as those described in the preceding paper.

\section{Pyloric obstruction. Dog number 266. (Table 1)}

In this table are given figures which illustrate the typical changes observed in the blood of a dog with simple pyloric obstruction. The principal changes demonstrated in this experiment are: (1) The relative cell volume increased in the second blood sample but decreased again in the third sample. The erythrocyte size was unchanged in the last sample, but ordinarily there is observed a slight diminution in this value. (2) The hemoglobin content of the cells remained practically unchanged, demonstrating that in this important constituent the red cells remained normal. (3) The serum protein and the nonprotein nitrogen increased. (4) The chloride fell markedly in both plasma and cells. (5) The $\mathrm{CO}_{2}$ content of both plasma and cells increased in the second sample, but fell terminally, presumably because of the increase of organic acids which is to be expected at this time. (7) There was a marked increase of the organic acid-soluble ester-P of the cells, evident in the figure for this fraction in the packed cells (84.5 mgm. per $100 \mathrm{cc}$.) and in the ratio of Ester-P : RBC count. The next greatest change of the blood phosphorus was in the inorganic fraction in the plasma.

\section{Pyloric fistula + histamine. Dog number 262. (Table 2)}

In this dog, under ether anesthesia, the pylorus was severed, the distal stump inverted and sutured and a pyloric fistula created through the abdominal wall. With a soft rubber tube in the fistula opening, the dog was kept in a frame for the collection of the gastric secretions. 
TABLE 1

Dog number 266. Pyloric obstruction. Allowed water ad lib., starting 18 hours after operation. Lived 71 hours

\begin{tabular}{|c|c|c|c|}
\hline & \multirow{2}{*}{ Normal } & \multicolumn{2}{|c|}{ Hours after operation } \\
\hline & & 48 & 70 \\
\hline 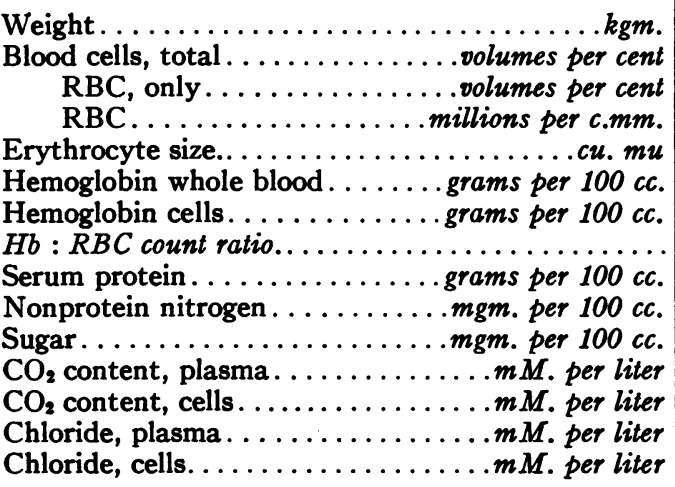 & $\begin{array}{c}23.2 \\
51.5 \\
50.1 \\
7.91 \\
63.3 \\
17.19 \\
34.3 \\
2.17 \\
9.2 \\
30^{*} \\
91 \\
22.0^{*} \\
13.0^{*} \\
106.0^{*} \\
58.0^{*}\end{array}$ & $\begin{array}{l}10.6 \\
100 \\
163 \\
32.76 \\
18.84 \\
78.5 \\
36.8\end{array}$ & $\begin{array}{c}20.1 \\
50.8 \\
48.9 \\
7.75 \\
63.1 \\
17.12 \\
35.0 \\
2.21 \\
11.0 \\
169 \\
35.3 \\
27.44 \\
14.25 \\
73.5 \\
28.2\end{array}$ \\
\hline \multicolumn{4}{|l|}{ Phosphorus distribution } \\
\hline 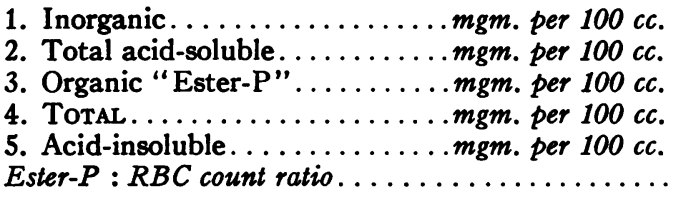 & $\begin{array}{c}3.2 \\
29.4 \\
26.2 \\
49.1 \\
19.7 \\
3.31\end{array}$ & $\begin{array}{l}5.26 \\
42.2 \\
36.94 \\
69.0 \\
26.8 \\
4.35\end{array}$ & $\begin{array}{c}8.77 \\
52.2 \\
43.43 \\
76.2 \\
24.0 \\
5.6\end{array}$ \\
\hline 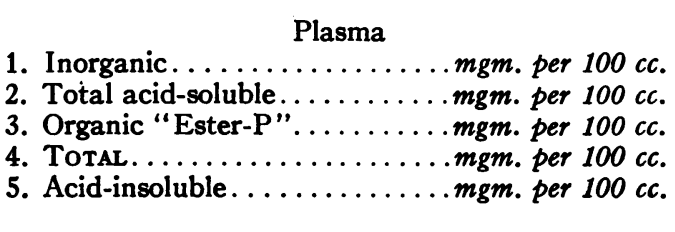 & $\begin{array}{r}3.8 \\
4.2 \\
0.4 \\
21.6 \\
17.4\end{array}$ & $\begin{array}{c}7.47 \\
8.16 \\
0.7 \\
29.7 \\
21.5\end{array}$ & $\begin{array}{r}13.8 \\
14.8 \\
1.0 \\
34.4 \\
19.6\end{array}$ \\
\hline 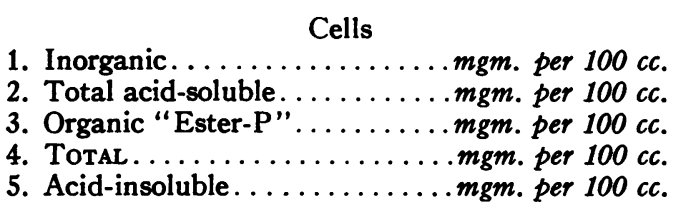 & $\begin{array}{c}2.63 \\
53.1 \\
50.5 \\
75.0 \\
21.9\end{array}$ & $\begin{array}{l}3.55 \\
68.5 \\
65.0 \\
99.4 \\
30.9\end{array}$ & $\begin{array}{c}3.90 \\
88.4 \\
84.5 \\
116.7 \\
28.3\end{array}$ \\
\hline
\end{tabular}

* Assumed normal values, taken for comparison.

† The RBC count was lost in this second sample. Assuming that the erythrocyte size did not change, the RBC count in the second sample would be 8.48 millions per c. $\mathrm{mm}$. The value 4.35 for the ester-P ratio is interpolated from this figure. 
After apparent recovery from the anesthesia, 3 hours after operation, $1 \mathrm{mgm}$. doses of histamine in $1 \mathrm{cc}$. of 0.9 per cent $\mathrm{NaCl}$ solution were injected subcutaneously at half-hourly and hourly intervals. These injections were continued until the dog died at the end of 16 hours (19 hours after the operation) by which time a total of $20 \mathrm{mgm}$. of histamine had been injected. During the first 12 hours of the injections the flow of gastric juice was almost continuous, observed as a small thin mucoid stream which was visibly accelerated by each injection of histamine. After 12 hours, the flow diminished considerably, and the response to each injection of histamine was much less. The total gastric secretions collected contained the equivalent of $1050 \mathrm{cc}$. of $\mathrm{N} / 10 \mathrm{HCl}$. Complete analyses on the preliminary small blood sample

TABLE 2

Dog number 262. Pyloric fistula + histamine. Died 16 hours after start of hourly subcutaneous injections of $1 \mathrm{mgm}$. histamine

\begin{tabular}{|c|c|c|}
\hline & Normal & $\begin{array}{c}\text { After histamine } \\
\text { injections }\end{array}$ \\
\hline 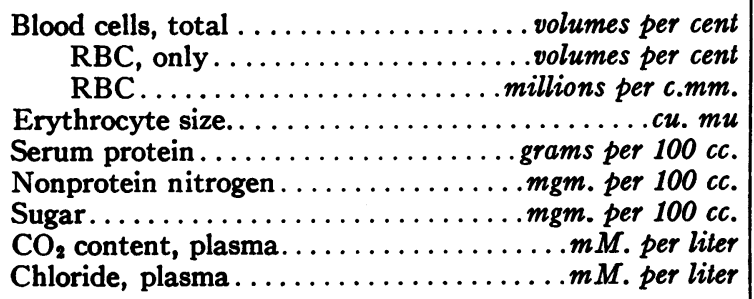 & $\begin{array}{l}47.8 \\
46.3 \\
6.60 \\
70.1 \\
7.0 \\
25 \\
90 \\
22 \\
108.5\end{array}$ & $\begin{array}{l}45.2 \\
43.6 \\
6.58 \\
66.2 \\
10.8 \\
64 \\
50 \\
38.5 \\
89\end{array}$ \\
\hline Phosphorus distribution & & \\
\hline 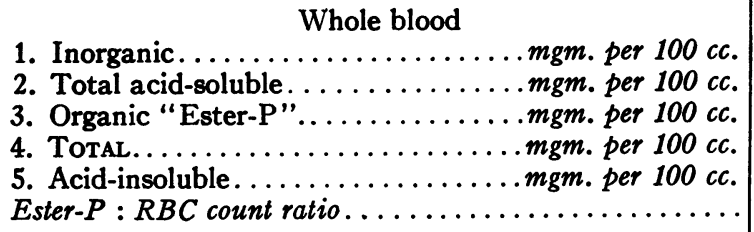 & $\begin{array}{l}2.38 \\
27.2 \\
24.82 \\
42.5 \\
15.3 \\
3.75\end{array}$ & $\begin{array}{l}4.76 \\
37.7 \\
32.94 \\
59.3 \\
21.6 \\
5.00\end{array}$ \\
\hline 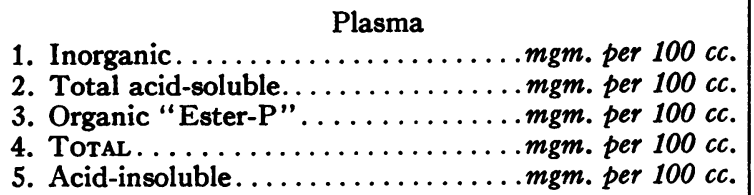 & $\begin{array}{c}2.72 \\
3.33 \\
0.6 \\
12.4 \\
9.07\end{array}$ & $\begin{array}{c}6.9 \\
7.25 \\
0.35 \\
25.5 \\
18.25\end{array}$ \\
\hline 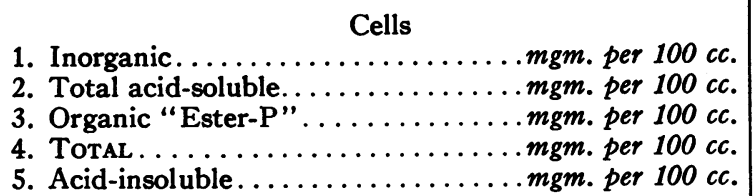 & $\begin{array}{c}2.01 \\
53.2 \\
51.2 \\
75.4 \\
22.1\end{array}$ & $\begin{array}{c}2.17 \\
74.6 \\
72.4 \\
100.3 \\
25.7\end{array}$ \\
\hline
\end{tabular}


taken before operation were not made; in the first column of Table 2 are listed for comparison the figures for nonprotein nitrogen, $\mathrm{CO}_{2}$ content, $\mathrm{Cl}$ and phosphorus distribution determined in the blood of a normal dog which had approximately the same relative cell volume, cell count, and hemoglobin. In the blood sample taken just before death (second column, Table 2) note especially the following values: (1) elevated serum protein and nonprotein nitrogen; (2) the low $\mathrm{Cl}$ and high $\mathrm{CO}_{2}$ content of the plasma; (3) the increased phosphorus content of the cells, the increase being practically all in the ester-P fraction. In this last blood sample were found values of such magnitude of change from the normal as have been observed in the blood of dogs with simple pyloric obstruction (i.e., without histamine injections, or other treatment) only at 48 to 72 hours or longer after operation; in this dog these changes developed in the brief course of 19 hours after operation, or only 16 hours after the histamine injections were started.

Normal dog injected with histamine; followed by pyloric obstruction and repeated histamine injections. Dog number 272. (Table 3)

A normal dog was subjected to hourly subcutaneous injections of 1 mgm. of histamine, in $1.0 \mathrm{cc}$. of 0.9 per cent $\mathrm{NaCl}$ solution, for 48 hours. Food was withheld. Throughout this period the animal manifested no outward signs of ill effects of the injections at any time. Blood samples were taken for analysis before the injections were started and again at 24 and 48 hours. After 16 days of rest a pyloric obstruction was created and immediately after recovery from the ether anesthesia the dog was subjected to the same hourly subcutaneous injections of histamine as before. Blood samples were again taken at the intervals indicated in the table. Since it was undesirable to draw large blood samples, complete analyses were not done on the preliminary blood samples taken before each of these experiments. The injections of histamine in the unoperated animal were almost without significant effect on the blood. There was a slight but measurable diminution in size of the erythrocytes, 65.5 to $62.4 \mathrm{cu}$. microns, and a slight diminution of the chloride, more noticeable in the cells. The ester-P of the cells increased slightly. After pyloric obstruction, 16 days later, the same injections of histamine were attended by rapid changes in the blood, as follows: (1) Concentration of the blood, indicated by the increasing red blood cell count and increased serum protein. (2) Loss of chloride and increase of $\mathrm{CO}_{2}$ in both plasma and cells. (3) Increases of the total phosphorus, practically all in the ester-P fraction in the cells. These changes were in no wise different from those observed in other dogs with simple pyloric obstruction, but developed much more rapidly. In the last blood sample, taken 1 hour before death (22 hours after operation) after 16 injections of $1 \mathrm{mgm}$. doses of histamine, the magnitude of changes in the blood is, as in the previous experiment, 


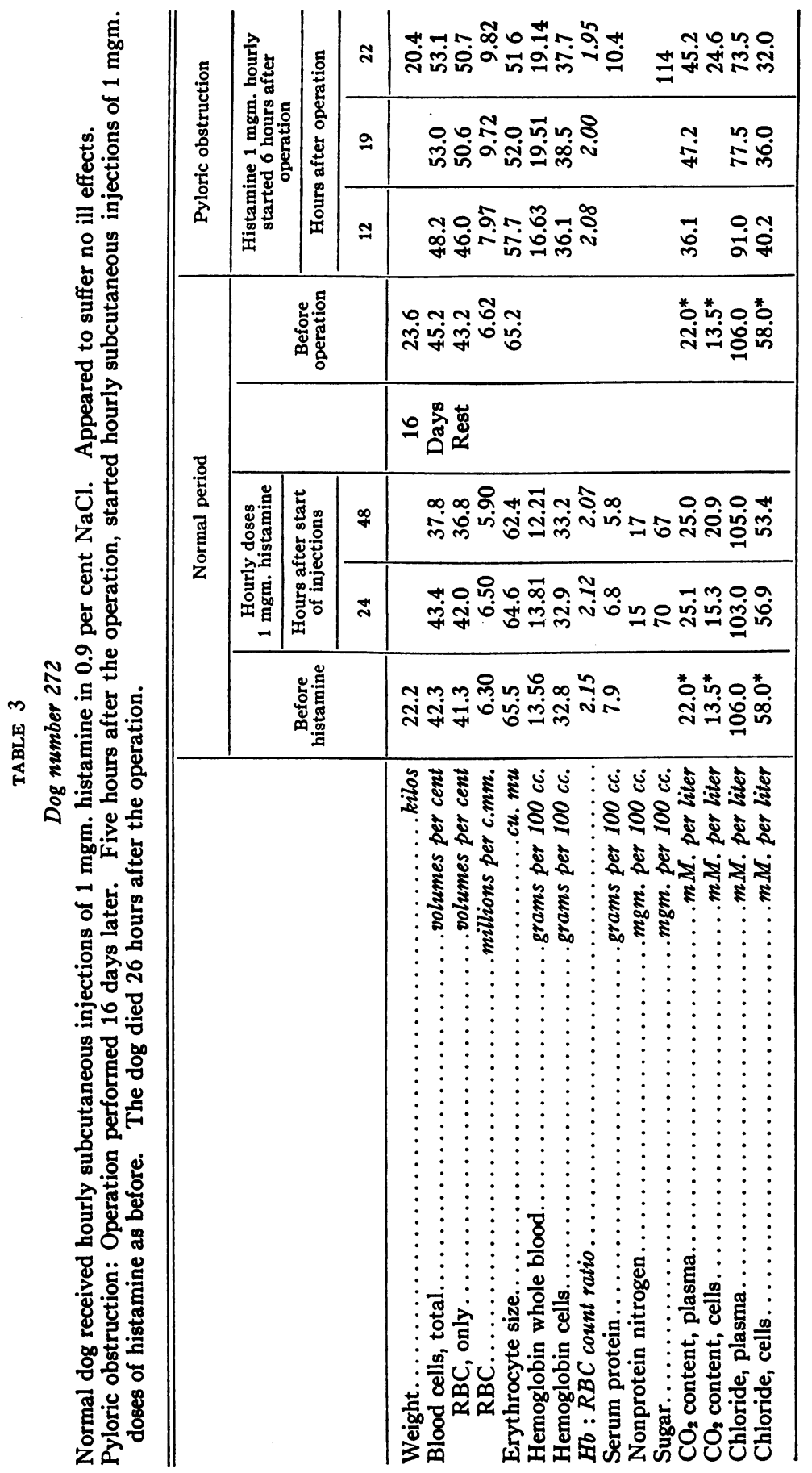


W. D. ANDRUS, G. M. GUEST, R. F. GATES AND A. ASHLEY 483

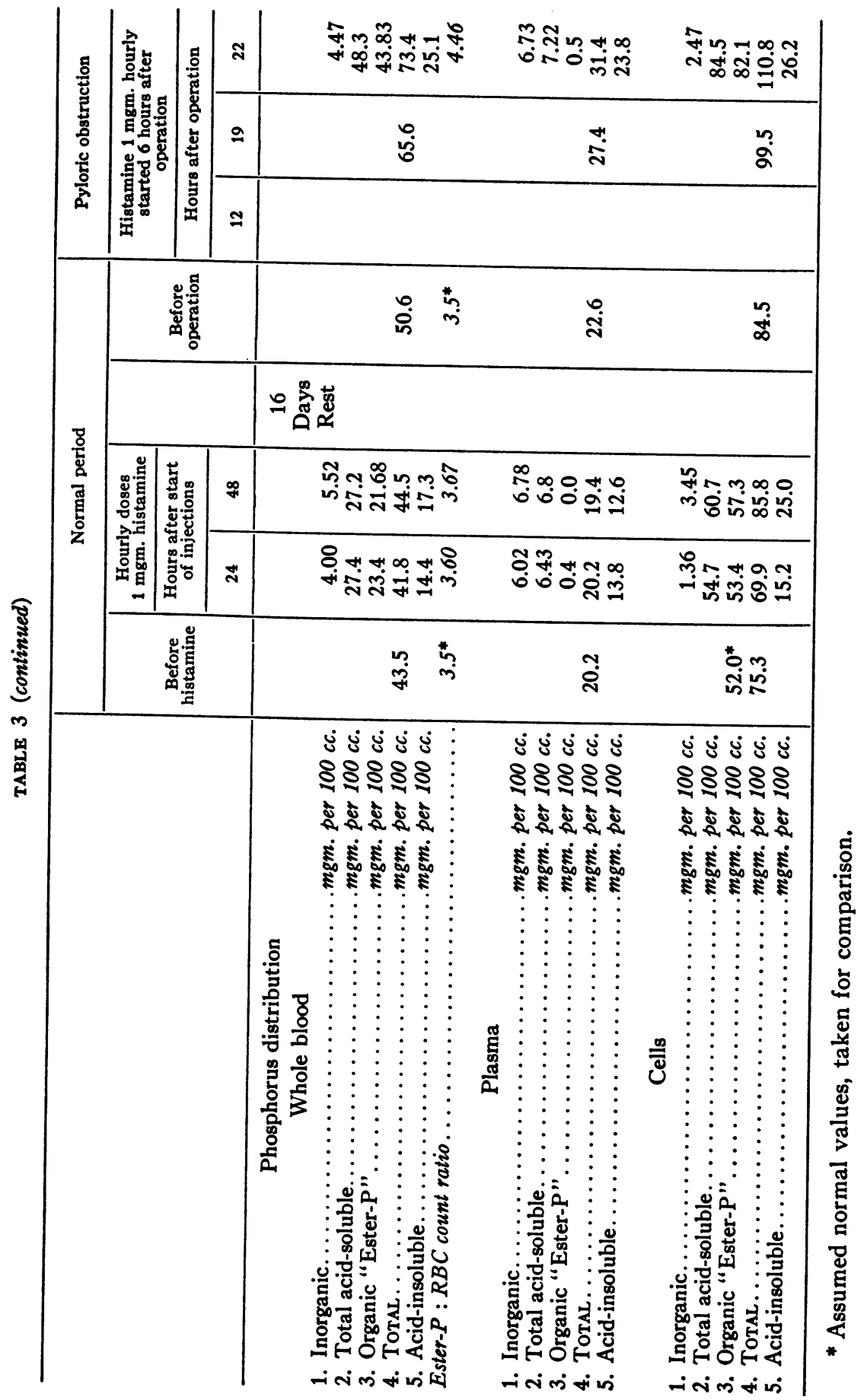


approximately that seen in dogs with simple pyloric obstruction at 48 to 72 hours, or longer, after operation.

\section{Pyloric obstruction + salt solution + histamine. Dog number 297. (Tables 4 and 5)}

In dogs with simple pyloric obstruction the parenteral administration of $\mathrm{NaCl}$ solution in appropriate amounts (around $50 \mathrm{cc}$. or more per kilo) prolongs life in the animals and diminishes the alterations of the blood,

TABLE 4

Time schedule of the experiment shown in Table 5 for dog number 297

\begin{tabular}{|c|c|c|c|}
\hline $\begin{array}{l}\text { Hours after } \\
\text { operation }\end{array}$ & $\begin{array}{l}0.9 \text { per cent } \\
\mathrm{NaCl} \text { solution }\end{array}$ & $\begin{array}{l}\text { Number of } \\
\text { blood sample }\end{array}$ & Notes \\
\hline & $c c$. & 1 & $\begin{array}{l}\text { Weight before operation, } 21 \text { kgm. Sample } \\
\text { taken } 24 \text { hours before operation. }\end{array}$ \\
\hline $\begin{array}{l}\frac{1}{2} \ldots \ldots \ldots \\
22 \ldots \ldots \\
30 \ldots \ldots \\
36 \ldots \ldots \\
48 \ldots \ldots \\
52 \ldots \ldots \\
54 \ldots \ldots \\
60 \ldots \ldots \\
72 \ldots \ldots \\
78 \ldots \ldots \\
78 \ldots \\
\ldots\end{array}$ & $\begin{array}{l}1500 \\
1000 \\
1350 \\
1000 \\
\\
1500 \\
1200 \\
1000\end{array}$ & 3 & $\begin{array}{l}\text { Histamine } 1 \text { mgm. in } 1 \text { cc. } 0.9 \text { per cent } \mathrm{NaCl} \\
\text { solution; hourly injections started immediately } \\
\text { after } 2 \text { nd blood sample was taken, and con- } \\
\text { tinued through } 48 \text { hours. }\end{array}$ \\
\hline
\end{tabular}

as described in the first paragraph of this paper. If the effect of histamine in hastening death in obstructed dogs is mainly one of stimulating gastric secretion and thus accelerating the losses of chloride from the body, then the administration of salt solution in sufficient amounts theoretically should protect these dogs as well as those with simple obstruction. The following experiment was performed to determine whether such protection could be obtained.

In a dog weighing $21 \mathrm{kgm}$. the pylorus was obstructed, under ether anesthesia, with the usual technic. Immediately after operation $1500 \mathrm{cc}$. of salt solution were given subcutaneously. Again at 22 hours after operation $1000 \mathrm{cc}$. of salt solution were given. At 30 hours after operation a blood sample was taken and immediately afterwards hourly subcutaneous injections of $1 \mathrm{mgm}$. histamine in $1.0 \mathrm{cc}$. 0.9 per cent $\mathrm{NaCl}$ solution were started. (This interval of 30 hours before starting the histamine injections was allowed so that the dog might recover from the immediate effects of the anesthesia and operation. A repetition of this experiment, in which both the histamine injections and the parenteral administration of salt solution were started immediately after operation, gave almost exactly the same results as shown here, so this time interval appeared to 
TABLE 5

Dog number 297. Pyloric obstruction + salt solution; hourly injections of histamine for 48 hours

\begin{tabular}{|c|c|c|c|c|}
\hline $\begin{array}{l}\text { Hours after operation......... } \\
\text { Number of blood sample.... }\end{array}$ & $\begin{array}{c}\text { Before } \\
1\end{array}$ & $\begin{array}{r}30 \\
2\end{array}$ & $\mathbf{5 2}$ & $\begin{array}{r}78 \\
4\end{array}$ \\
\hline 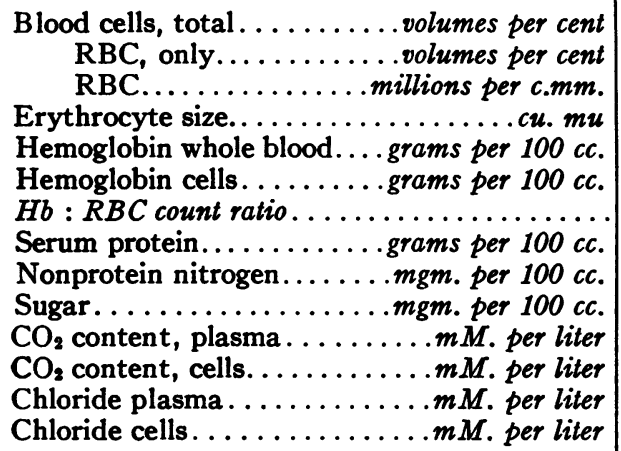 & $\begin{array}{l}44.2 \\
43.1 \\
6.45 \\
66.8 \\
15.76 \\
36.5 \\
2.44 \\
7.8 \\
30^{*} \\
90^{*} \\
22.0^{*} \\
13.0^{*} \\
111.0 \\
60.1\end{array}$ & $\begin{array}{c}49.9 \\
48.3 \\
8.20 \\
58.9\end{array}$ & $\begin{array}{c}8.72 \\
20 \\
85 \\
32.1 \\
17.4 \\
113.0 \\
40.7\end{array}$ & $\begin{array}{c}40.9 \\
39.6 \\
6.45 \\
61.4 \\
15.44 \\
39.0 \\
2.39 \\
7.44 \\
25 \\
59 \\
32.8 \\
18.4 \\
114.5 \\
59.5\end{array}$ \\
\hline \multicolumn{5}{|l|}{ Phosphorus distribution } \\
\hline 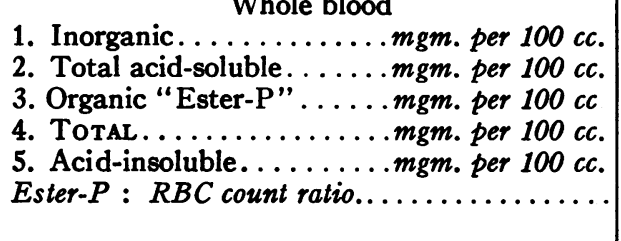 & $\begin{array}{l}3.12 \\
24.6 \\
20.5 \\
40.0 \\
15.4 \\
3.18\end{array}$ & $\begin{array}{l}3.02 \\
32.3 \\
29.3 \\
48.7 \\
16.4 \\
3.57\end{array}$ & $\begin{array}{r}2.7 \\
34.5 \\
31.8 \\
51.5 \\
17.0 \\
3.74\end{array}$ & $\begin{array}{l}3.24 \\
29.4 \\
26.16 \\
45.0 \\
15.6 \\
4.05\end{array}$ \\
\hline 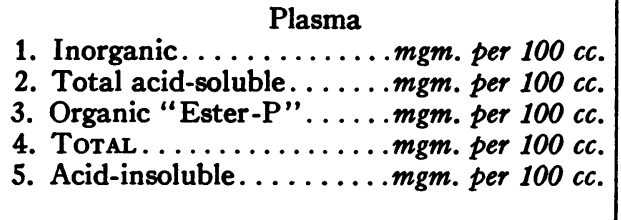 & 14.6 & 17.1 & 17.4 & $\begin{array}{c}2.92 \\
4.32 \\
0.4 \\
15.0 \\
10.7\end{array}$ \\
\hline $\begin{array}{l}\text { Cells } \\
\text { 1. Inorganic..............mgm. per } 100 \mathrm{cc} . \\
\text { 2. Total acid-soluble......mgm. per } 100 \mathrm{cc} . \\
\text { 3. Organic "Ester-P".....mgm. per } 100 \mathrm{cc} . \\
\text { 4. TotaL..............mgm. per } 100 \mathrm{cc} . \\
\text { 5. Acid-insoluble.........mgm. per } 100 \mathrm{cc} .\end{array}$ & $\begin{array}{l}47.5 \dagger \\
72.0\end{array}$ & $\begin{array}{l}58.7 \dagger \\
80.4\end{array}$ & $\begin{array}{l}65.7 \dagger \\
87.8\end{array}$ & $\begin{array}{l}2.26 \\
65.6 \\
63.4 \\
88.3 \\
22.7\end{array}$ \\
\hline
\end{tabular}

* Assumed normal values, taken for comparison.

$\dagger$ Where the complete analyses of plasma were not made, the organic ester-P of the cells was calculated without allowing for the slight amount of ester-P in the plasma. The error thus introduced is negligible.

be unimportant.) Salt solution was again given at 36 hours and 48 hours, and another blood sample was taken at 52 hours after operation. (See the time schedule of the experiment in Table 4.) In this blood sample No. 3 the cell chlorides were found to be low and in the next 24 hours the administration of salt solution was increased. (See Table 4.) In 
the last blood sample, at 78 hours, the chlorides of both plasma and cells were again at practically the initial level. The nonprotein nitrogen had remained normal. The total phosphorus of the cells increased, and the figure for the Ester-P : RBC count ratio steadily increased, but these increases in the cell $\mathrm{P}$ are not nearly as great as those shown after simple pyloric obstruction in Table 1 . The changes in the plasma phosphorus were negligible.

The dog was sacrificed after the blood sample taken 78 hours after operation (48 hours of histamine injections). The experiment had been continued long enough to demonstrate that the dog could be kept alive by the parenteral administration of salt solution well beyond the time at which death occurred in dogs with obstruction, similarly injected with histamine but not receiving salt solution. Were it not for the exigencies of the experiment-the large blood samples that had been taken, etc.it seems likely that this dog could have been kept alive for even a longer time by this treatment.

\section{DISCUSSION}

In these experiments it is demonstrated that when dogs with pyloric fistula or pyloric obstruction are injected with small repeated doses of histamine, they develop more rapidly all the chemical changes of the blood which are ordinarily associated with intestinal obstruction, and die much more quickly than do the untreated dogs with simple obstruction. In normal unoperated dogs similar injections of histamine continued for even longer periods were without visible deleterious effects and caused only slight changes in the blood. Histamine thus injected is known to have a powerful effect in stimulating the secretion of gastric juice. In normal animals these secretions presumably pass through the pylorus into the intestine to be reabsorbed and again form part of the body fluids. However, in animals with obstruction and vomiting, such stimulation of the gastric secretion must accelerate the losses of gastric secretions from the stomach and therefore hasten the development of all the chemical changes which occur in the body in consequence of these losses. If one accepts the existing evidence that the alterations of the blood and body fluids ordinarily observed in simple high obstruction are due mainly to the losses of water and electrolytes by vomiting, it seems reasonable to believe that the same mechanism is operative in producing the altogether similar changes that are observed when dogs with obstruction are injected with histamine. It seems unnecessary to postulate a general toxic action of the histamine on the body tissues to explain the effects of histamine in hastening death in the obstructed animals. The immediate death with the symptoms of "shock" that follows the intravenous injections of larger doses of histamine may be due to a different mechanism.

Work is in progress to determine whether or not the effects of subcutaneous injections of the toxic substances (proteoses or amines?) 
from the contents of the obstructed or strangulated intestine, or from closed loops in dogs, are closely analogous to this effect of histamine. The absorption of such substances conceivably might be sufficiently rapid to cause immediate death with manifestations like those observed after the intravenous injection of these toxic substances, but in clinical experience such a circumstance is certainly exceptional. It is likely that the slow absorption of these substances will be found to have an effect similar to that of histamine in stimulating the flow of gastric juice (Dragstedt and Dragstedt (1922)); if this be true, then it is possible that the most important effect of the slow absorption of toxic substances from a strangulated portion of bowel is not any general "intoxication" of the body tissues, but an acceleration of all those secondary effects which ultimately cause death.

In dogs with obstruction, injected with histamine, much more salt solution was necessary to maintain the blood chlorides at a normal level than in similarly obstructed dogs not receiving histamine injections. In Table 4 it is to be noted that even though the plasma chloride remained at a normal level in the obstructed dog receiving large amounts of salt solution parenterally along with the hourly injections of histamine, the cell chloride fell markedly, from $60.1 \mathrm{mM}$. before operation to 53.4 and $40.7 \mathrm{mM}$., in the blood samples taken at 30 and 52 hours, respectively, after operation. A larger amount of salt solution was given in the 24 hours before the last blood sample was taken, 78 hours after operation, and in this blood the cell chloride was again at the normal level. This observation of a fall in the chloride greater in the cells than in the plasma after histamine injections has been confirmed in several experiments, and was observed by Lim and $\mathrm{Ni}$ (1926) in their experiments mentioned in the early part of this paper. In several of the experiments with obstructed dogs, both with and without histamine injections, it has seemed to be more difficult to prevent the losses of $\mathrm{Cl}$ from the blood cells and the increases of ester-P in the cells than to maintain the plasma $\mathrm{Cl}$ at a normal level by means of the parenteral administration of $\mathrm{NaCl}$ solution. Much more work is needed to ascertain the significance of this in relation to treatment.

\section{SUMMARY}

In dogs with pyloric obstruction, repeated subcutaneous injections of small doses of histamine have the effect of hastening the development of those chemical changes in the blood which have been claimed by many to be the most important ultimate cause of death.

Histamine has been employed as a known substance which is at least closely related to the toxic substances which appear in the contents of a segment of obstructed or strangulated bowel. Histamine, injected subcutaneously as in these experiments, stimulates the flow of gastric juice 
and in the presence of vomiting such increased secretion results in more rapid losses of electrolytes and water than occur in animals with simple obstruction; in consequence of this there is a more rapid development of the whole cycle of the symptoms and chemical changes which ordinarily accompany intestinal obstruction.

From these experiments it is suggested that patients with intestinal obstruction plus strangulation, or dogs with experimental obstruction plus closed loops, die sooner than do those with simple obstruction not because of any specific general "intoxication" of the body tissues, but because the slow absorption of histamine-like substances from the bowel results in an acceleration of the progress of all those chemical changes which occur secondarily to the losses of gastic secretions.

\section{BIBLIOGRAPHY}

Cooper, H. S. F., Arch. Surg., 1928, xvii, 918. The Cause of Death in High Obstruction.

Davis, D. M., Bull. Johns Hopkins Hosp., 1914, xxv, 33. Intestinal Obstruction: Formation and Absorption of Toxin.

Dragstedt, L. R., Proc. Soc. Exp. Biol. and Med., 1928, xxv, 239. Blood Chemistry in Intestinal Obstruction.

Dragstedt, L. R., and Dragstedt, C. A., J. Am. Med. Assoc., 1922, Ixxix, 612. Acute Dilatation of the Stomach.

Drake, T. G. H., and Tisdall, F. F., J. Biol. Chem., 1926, lxvii, $91 . \quad$ The Effect of Histamine on the Blood Chlorides.

Gerard, R. W., J. Am. Med. Assoc., 1922, 1xxix, 1581. The Lethal Agent in Acute Intestinal Obstruction.

Guest, G. M., and Andrus, W. DeW., J. Clin. Invest., 1932, xi, 455. Chemical Studies of the Blood in High Intestinal Obstruction. I. The Distribution of Phosphorus and Intracellular Changes.

Lim, R. K. S., and Ni, T. G., Am. J. Physiol., 1926, lxxv, 475. Changes in the Blood Constituents Accompanying Gastric Secretions.

Murphy, F. T., and Brooks, B., Arch. Int. Med., 1915, xv, 392. Intestinal Obstruction; An Experimental Study of the Causes of Symptoms and Death.

Stone, H. B., and Firor, W. M., Tr. South. Surg. Assoc., 1924, xxxvii, 173. Absorption in Intestinal Obstruction; Intraintestinal Pressure as a Factor.

Van Buren, F. T., Ann. Surg., 1920, lxxii, 529, 610. Relation between Intestinal Damage and Delayed Operation in Acute Mechanical Ileus.

Whipple, G. H., Rodenbaugh, F. H., and Kilgore, A. R., J. Exp. Med., 1916, xxiii, 123. Intestinal Obstruction: V. Proteose Intoxication. Stone, H. B., Bernheim, B. M., and Whipple, G. H., Bull. Johns Hopkins Hosp., 1912, xxiii, 159. Intestinal Obstruction: A Study of the Toxic Factors. 